\title{
More than Meets the Eye. The Political Causes of the Asian Economic Crisis
}

\author{
JÜRGEN RUDOLPH AND INDIRA ARUMUGAM
}

'In nearly every economic crisis, the root cause is political, not economic.

Singapore's Senior Minister Lee Kuan Yew, addressing a top group of US CEOs at the FORTUNE 500 Forum in Boston (qtd. in Chow dhury and Paul 1997)

The havoc that the Asian economic crisis of the late 1990s wreaked seems to be on the wane. Economies seem to be recovering and tense political situations seem to be subsiding. However, the political contributions to the crisis have yet to be sufficiently addressed. These political causes are not as immediately plausible as many of the economic and financial ones. The use of the term 'political cause' in this paper has its origin in the widespread claims that economic and financial factors caused the crisis. As it is possible to cast serious doubt on the concept of cause, it is used here largely as a counter-concept and as a rhetorical device. The term, however, should not detract from the argument that corruption (including electoral manipulation) was a significant contributory factor to the crisis. This relationship is then augmented by the fact that the states most affected by the crisis are not yet fully fledged democracies. Such states tend to spawn a dependent judiciary, an insufficient separation of powers, controlled media and an underdeveloped civil society. 
There is growing empirical evidence to support the idea of a positive relationship between economic and political freedom. While economic freedom helps to establish the conditions for political freedom by promoting the growth of prosperous middle and working classes, successful market economies also require political freedom to provide a barrier against economic cronyism and other anti-competitive and inefficient practices (Karatnycky 1999: 122).

There are intricate inter-relationships between democratic institutions-such as parliament, an independent judiciary, free media and a thriving civil society-and low levels of corruption. Consequently, corrupt ruling elites find these democratic institutions to be nuisances. However, transparency and accountability appear to be fundamental requirements, not only for a consolidated democracy, but also for the competitive functioning of national economies. A lack of government accountability has contributed to the crisis, and rights such as Asian NGOs-particularly freedom of expression, association, and assembly-are critical to the kind of governance that may not only put the region's economies back on track (Jones 1999: 9), but also diminish the probability of future crises.

As a preliminary study, this paper will not track exactly how political factors affected the national economies of a specific 'crisis economy'. There is no implication of a direct and strict causal relationship between the flouting of democratic principles and the economic crisis. It would be spurious to adopt a post hoc ergo procter hoc ${ }^{1}$ type of argument. However, general considerations of how politics influences economic performance are offered.

Many politico-economic elites argue for a strictly economic view of good governance. In this view, human rights consist primarily of access to basic necessities, and material prosperity should be the principal consideration, not political maturity. Such a view contravenes the conception of good governance as put forward by the World Bank, the International Monetary Fund (IMF) and the United Nations (UN). The UN defines good governance as 'systems of government required to encourage people's involvement in decision-making, stimulate economic 
Jürgen Rudolph and Indira Arumugam

growth and ensure that the benefits of that growth reach all segments of society'. (UNDP 2000). Many of the elements that this paper argues as contributing to the crisis and its prolongation are also emphasized by the UN, thus eschewing a strictly materialistic conception of good governance and rights. Following that, this paper argues that good governance as defined by many of these elites does not, and must not, preclude democratization. Otherwise, good governance will be a mere euphemism for authoritarianism. In fact, they are, and must be, mutually dependent. This view is also shared by Korean President Kim Dae Jung, who has traced the problems of his country to the 'placing of economic development ahead of democracy' and argues that 'democracy and a free market economy can and must flourish together, as one' (quoted in Lee 2000: 177). How applicable is Kim's observation to the other 'crisis economies' in the region?

This paper resists the temptation to posit that any of the aforementioned candidates for 'political causes' triggered the crash. But it will assert that these were contributory factors to the crash and 'contagion', and that they prolonged the crisis. It will cast doubt on two notions that are popular even two years after the advent of the crisis. One being that the crisis was a result of purely financial or economic factors and the other that countries such as Thailand, South Korea and Indonesia were all doing just fine until the greedy forces of globalization disrupted them. It is argued that the lack of sound democratic practices provided suitable host conditions for the proliferation of a myriad of economic ills. Examples will be cited mainly from the five countries most affected by the crisis, namely Thailand, Indonesia, Malaysia, Korea and the Philippines.

The potential political causes refer to incomplete democratization. This paper will use Larry Diamond's definition of liberal democracy which addresses the fallacy of electoralism that underpin most other definitions (e.g. Schumpeter 1947: 269). Diamond's definition goes beyond regular, free and fair electoral competition and universal suffrage, which is only a part of full political democracy. He identifies necessary requirements, the absence of which will be discussed as the possible 
political causes of the crisis. Diamond sees liberal democracy incorporating the constraint of executive power by the autonomous power of other government institutions. Civil liberties (such as freedom of belief, opinion, discussion, speech, publication, assembly, demonstration and petition) are effectively protected by an independent, non-discriminatory judiciary, whose decisions are enforced and respected by other centres of power. The rule of law protects citizens from unjustified detention, exile, terror, torture or undue interference in their personal lives. Diamond's definition also encompasses associational freedom and the existence of a diverse array of autonomous associations, movements and groupings. Alternative sources of information must also exist, such as independent media to which citizens should have ready access (Diamond 1999: 10-13).

It cannot be denied that economic factors contributed to the crisis. Within the economic discourse, 'external aspects' (fixed exchange rates, high interest rates and excessive borrowing from abroad) are perceived to have been among the important causal factors of the crisis. However, many academics like Karl Jackson (1999: 5) have argued that the crisis would not have occurred without the following 'internal aspects': 'inadequate supervisory institutions, traditional banking practices, and, most of all, poor investment decisions made by the private sector of each country. ${ }^{2}$

Much of the economic malaise can be attributed to a general lack of transparency and accountability, which rendered inadequate economic and financial policies possible in the first place. The worst-affected countries generally exhibited less transparent and less effective corporate and financial regulatory systems; in particular, there was a lack of public participation in reviewing financial arrangements (Sen 1999b: 9). It is the basic hypothesis of this paper that this lack of transparency and accountability applies to the prevailing systems of government in the region in general, albeit in varying degrees. In the following discussion of the political causes of the crisis, the attempt will be made to show that a lack of transparency and accountability, at the very least, greatly aggravated the crisis. 
Jürgen Rudolph and Indira Arumugam

\section{Political Causes}

\section{Corruption, Collusion, Cronyism}

Complicity between governments, bureaucracies and conglomerates characterizes much of Asian politics. Indonesia under Suharto was the region's most corrupt country (see Transparency International 1998) and a prime example of a kleptocratic state. ${ }^{3}$ While the Indonesian excesses are extreme, it is argued that collusion and corruption are almost endemic to the worst-affected 'crisis economies'. Market-economy systems are only partially in place in many Asian countries. Often, there is no fully fledged competition due to monopolies, oligopolies, corruption, nepotism, favouritism, state interventionism and protectionism. In the aftermath of the crisis, crony capitalism which eschews control and transparency whilst nurturing paternalism and nepotism has fallen into great disrepute.

Asian political systems in general are not transparent. Constitutional principles such as separation of powers or guarantees of basic rights are only partially in place. National differences notwithstanding, the power is largely with politicoeconomic elites who are beyond almost any control. From the monopolistic enterprises of the Suharto children to the chaebol family-based conglomerates in South Korea, Asian politics is characterized by conglomerates that are intimately linked to the governments and bureaucracies. These ruling elites consider transparency and accountability as embodied by powerful parliaments, a free press, an independent judiciary and the control and supervision of cartels and banks to be threatening.

Cronyism and corruption have often been cited as major factors in the Asian crisis. François Godement (1999: 55) has noted correctly that 'the past implication of foreign firms and businessmen in the pattern of corruption makes many protests sound hypocritical.' Nonetheless, cronyism has perverted the relationship between state and market and has undermined the sound economic fundamentals of East and Southeast Asia. According to the Asian Development Bank's annual report, 'corruption has added 20 to 100 per cent to the cost of procuring 
government goods and services in several Asian countries' (Straits Times, 27 April 1999). In Thailand itself, households shell out an annual US\$625 million to bribe-taking bureaucrats (East 2000).

The implication of corruption in the crisis has been particularly forcefully applied to the Indonesian case. Apart from rampant political corruption, the depth of the Indonesian crisis was also attributable to other political factors such as the political instability surrounding Suharto and his impending succession, the lack of good governance, and the repression of all political opposition (Sadli 1999: 16-18; McLeod 1999: 218). Although most of these missing 'political fundamentals' were observable during the entire duration of the long Suharto era, there seems to be an expiration date on such repressive forms of governance, especially in the context of a fast-changing region with the concomitant pressures of industrialization and globalization. The Suharto regime certainly fits into the category of a 'performance regime' that lacked non-economic sources of legitimacy. This type of regime has shown a tendency to collapse during an economic crisis (Jackson 1999b: 17). In addition, the Suharto regime had a strongly personalistic or sultanistic element which also made it more fragile (see Forrester and May 1999: 136).

Having said this, the role of corruption in Indonesia's fall can hardly be overestimated. For decades, the country was led like a family enterprise, with ex-President Suharto watching over politics and his six children dominating the economy. Aspirants to big business in Indonesia had to get the costly blessings of the Suharto clan. Michael Backman (1999) has identified 1,247 separate companies in which the Suharto family held a significant stake. Time magazine has alleged that former President Suharto - who, as president of Indonesia, earned Rp15 million (US\$1,800) a month - and his family are worth US $\$ 15$ billion.

The fast-growing business enterprises of Suharto's children, grandchildren, relatives and close associates were granted extraordinary favours by the Indonesian government. These companies did not have to compete for prime government 
contracts. They also had ready access to cheap funds from state banks (McLeod 1999: 214ff.). The Indonesian government under Suharto served the interests of a narrow elite rather than the public at large, and rampant corruption came to infect all areas of public life (McLeod 1999: 215; Schwarz 1994: 133-161). The Indonesian case is an extreme one. But almost everywhere in the region, politics, administration, the private sector and banks are inextricably intertwined to varying degrees. Thailand, on the other hand, has been far more democratic than Suharto's Indonesia because of the success of the Thai civic movement against General Suchinda Kraprayoon's coup d'état. But rampant corruption also taints Thailand, largely taking the form of competitive clientelism as opposed to Indonesia's monopolistic clientelism. While in Indonesia, power was concentrated in President Suharto and the officers and bureaucrats nearest to him, in. Thailand different portions of the business elite competed for patronage from different parts of the political elite (see Doner and Ramsay 1999; Jackson 1999b).

Some adherents of 'Asian values' have argued that the relative economic backwardness of the Philippines is due to its Americanized democratic governance. However, Ferdinand Marcos-who was initially popularly elected but went on to become a dictator during his 20-year rule-has to be largely blamed for this country's economic shortcomings. Marco's nationalistic crony capitalism protected various sectors of the economy from outside competition to the benefit of his friends and the long-term detriment of the nation (Mallet 1999: 278). Marcos and his cronies looted the country, and 'the hundreds of millions siphoned away translated into billions in lost opportunities' (Delhaise 1998: 162). Politics in the Philippines is still heavily influenced by big land-owning families, which have vast powers of patronage. Corruption reigns in the Philippines to the extent that policemen have been implicated in the kidnappings of ethnic Chinese businessmen.

In Malaysia, an ethnicity-based economic policy which favours indigenous bumiputras (mostly ethnic Malays) has inaugurated a new generation of Malay entrepreneurs. Much of their success is based on protectionism and favouritism, 
although the extent of this collusion has not reached the excesses of Indonesia. Nonetheless, Malaysia's Prime Minister Mahathir, in a speech to UMNO members about 'money politics', wept and said he feared that corruption, if left unchecked, would 'destroy the country' (Mallet 1999: 255). Former Deputy Prime Minister Anwar Ibrahim, who is serving a jail term for corruption, has claimed to be the victim of a plot by government leaders, who are responding to his threat to expose their corrupt practices.

The success of many Asian businesses can be attributed not to their sound management practices but to their collusion with a corrupt government. Malaysia ranked in the middle, while Thailand, the Philippines and Indonesia languished at or near the bottom with regard to corruption in the Global Competitive Survey (see Sachs 1999: 12). Whole economies were protected from competition both by formal laws and by the informal influence of government cronies. The rise of a class of businessmen doing business based on 'know-who' rather than 'know-how' proved ultimately disastrous. Collusion between government and business has become increasingly untenable in an era of global competition. This was once disguised by decades of fast economic growth but has eventually come to the fore.

Before we conclude this section, two relationships deserve consideration: the first between democracy and corruption. At first glance, there does not appear to be an unequivocal and direct correlation between lack of corruption and democracy. For instance, the world's largest democracy, India, is plagued by corruption. In Salman Rushdie's novel, The Moor's Last Sigh, one of the characters sardonically offers his definition of modern Indian democracy ('one man one bribe') and of what he calls the 'Indian Theory of Relativity' ('everything is for relatives') (Rushdie 1997: 21). Singapore, on the other hand-which is frequently placed in the 'soft authoritarian' camp-is relatively outstanding in its honesty and efficiency. This has been achieved by an uncompromising anti-corruption policy, strict policing of the population, and the very high salaries paid to top civil servants and government ministers. ${ }^{4}$ In 
Jürgen Rudolph and Indira Arumugam

comparison, the two most democratic states in Southeast Asia, Thailand and the Philippines, are riddled with corruption.

It is difficult to draw precisely a direct relationship between democracy and corruption. Democracy does not guarantee lack of corruption. On the other hand, non-democratic governance permits high levels of corruption due to the concentration of power and other ills, such as repressed media, a compliant judiciary and a general absence of checks and balances. In a democratic country, institutions such as a free press and an independent judiciary expose and punish corruption, thereby minimizing its incidence.

Huntington has argued that while democracy breeds corruption among political parties and politicians in the short term, it also allows strong political parties to develop which will counter corruption in the long term (see Pasuk and Sungsidh, 1996: 21). This hypothesis would be in accordance with the assessment by many political scientists that relatively young democracies, such as Thailand and the Philippines, still exhibit numerous democratic deficiencies and thus have a long way to go. However, corruption constitutes a major threat to the future of democracy itself in many parts of the world, not only in East and Southeast Asia. It is therefore ill advised to dismiss such a threat as temporary or as merely a means to the end that is liberal democracy.

The second relationship, that between corruption and development, should be considered in the light of the oft-voiced contention that corruption and collusion-although deplorable from a moral point of view-speed up economic development. For instance, Philippe Delhaise (1998: 104) opines that collusion between politicians, big business and banks leads to much dynamism for which 'corruption at the top is perhaps a small price to pay'. This is the strong version of a strand of thought which denies any negative impact of corruption on development. In fact, it views corruption as having a positive impact on development. There also exist weaker versions of this argument. These run along the line that although not good in itself, corruption does not appear to have a detrimental effect on a nation's economy. For example, Hal Hill points to the 
observation that corrupt administrations (in East and Southeast Asia as well as elsewhere) have presided over rapid economic development in the past, in the process earning such triumphalist epithets as 'Asian Miracle', 'The Asian Century' and 'Asian Tigers': China, Taiwan and Indonesia are cases in point. These arguments, however, are less than convincing.

In fact, corruption has a multiplicity of bad effects on both economic and political development. Although the fall-out from years of fraudulent economic and political activities was not immediately apparent, it would not be incorrect to argue that such activities laid the foundation for the crisis of 1997. For even amidst the economic boom, the ill effects of corruption were still present, albeit disguised by skyrocketing stock figures and flourishing property markets. Shang and Sievers (1999) argue that contrary to Delhaise's and Hill's convictions, 'Asian performance would have been better had levels of corruption been lower. In this sense, corruption in parts of Asia caused the regions to underperform when compared to potential accomplishment.' They calculate that 'if the Philippines, for example, could reduce its corruption levels to those of Singapore, it would increase, all other things being equal, its investment/ gross domestic product (GDP) ratio by 6.6 percentage points -quite a substantial increase.' Such countries are also finding it tougher to shake off the effects of the crisis compared to those that are relatively free of corruption.

So far, we have hypothesized that corruption is a serious problem in all five crisis economies, albeit in varying degrees. Moreover, we have seen that democracies are more likely to combat corruption than non-democratic states, and that there appears to be a strong correlation between economic development and economic freedom. The complex relationships between corruption, democracy and development will be further evaluated in the final section of this paper.

\section{Electoral Manipulation}

Electoral irregularities may have played a much neglected role in the genesis of the Asian economic crisis. Inadequate electoral systems play into the hands of ruling parties. In many pseudo- 
Jürgen Rudolph and Indira Arumugam

democratic nations, electoral fraud, manipulation and massive vote-buying are common practice and prevent a change in government. Electoral manipulation is a form of political corruption and constitutes an antithesis to the conduct of fair and free elections. As such, it contradicts a responsible use of power (cf. Leones and Moraleda 1998: 330).

In Thailand, the electoral system constituted a key weakness. Under the pre-crisis Constitution, the 200-member Senate was appointed by the prime minister, while the lower house was composed of $393 \mathrm{MPs}$ from multi-member constituencies based on a ratio of one MP to 150,000 people. A further weakness lay in the fact that provincial constituencies supplied approximately 80 per cent of the seats, with one-third of votes coming from the impoverished Northeast region alone. Doner and Ramsay (1999: 189) argue convincingly that 'such a system encouraged patronage-based rather than policy-based parties'. Linked to the electoral system was Thailand's combination of a parliamentary structure with multiple weak parties. Prime ministers had to struggle to keep their coalitions together. As a consequence, major policy initiatives, such as those demanded by the crash of 1997, were extraordinarily difficult to undertake.

Due to money politics, electoral success is largely determined by the availability of funds. Several recent prime ministers have taken office largely because of the number and power of their political allies. For instance, the ex-prime minister Banharn Silpa-archa started his term of office with the nickname 'Mr Automatic Teller Machine' because of his infamous vote-buying record (Sachsenröder 1998: 14).

The revenue from corruption is often a crucial element in building and maintaining a politician's power-base. Once in office, a politician must be able to maintain a flow of funds to his supporters and constituents in order to prove his worth and consolidate his chances of re-election (Pasuk and Sungsidh 1996: 15). In Thailand, there is the figure of the jao pho ('godfather') who has come to play a crucial role in parliamentary elections. The extremely well-connected 'godfathers' sit in positions of authority in local administration, but are not necessarily themselves in parliament. However, they may dictate the 
voting behaviour of several MPs for whom they have helped to secure election. The jao pho compete with the military and the bureaucracy for a share in the 'corruption money' (Pasuk and Sungsidh 1996: 57ff.).

It has been estimated that Thai politicians spent US $\$ 800$ million buying votes during the 1996 election campaign, described as the dirtiest ever. Not only votes but politicians with potential can also be bought. Other irregularities are connected with the preparation of the voter list, voting at the polling station and the counting of votes (Anusorn 1998: 425-437).

One of the most damaging aspects of this system was that politicians are under intense pressure to generate cash flows while in office-usually from corrupt business deals-to cover the vote-buying and network-maintenance expenses. Due to the weak political party system, party and faction leaders are also compelled to generate funds to hold their members together. As Singapore's Lee Kuan Yew recently pointed out, Thai politicians, who held personal stakes in many troubled financial institutions, have displayed 'a natural reluctance to discipline them' (Chowdhury and Paul 1997). The good news is that most voters in Bangkok at least are no longer prepared to tolerate corrupt politicians.

In pre-crisis Indonesia, there were two different types of elections: the general election and the presidential election. During the general elections-known as 'a festival of democracy' but bearing little semblance to the real thing-only three political parties were allowed to compete for the 425 seats of the House of Representatives (DPR) or parliament. Another 75 were appointed to represent the armed forces. Every five years, the $500 \mathrm{MPs}$ were joined by another 500 members appointed by the president to form the People's Consultative Assembly (MPR), whose 1,000 members then elected the president and vice-president. The polls were widely believed to be largely rigged. In the general elections in 1997, double vote-counting was rife, and civil servants (for whom it was compulsory to vote for Golkar, the ruling party) were posted special extra voting cards, allowing them to vote at work as well as in their home town (Kearney 1999). 
Jürgen Rudolph and Indira Arumugam

In Malaysia, gerrymandering is common. It seems to be a common practice that opposition strongholds are carved out and integrated into areas controlled by the ruling Barisan Nasional. Elections in Malaysia are less than fair as campaigns are conducted in a way that tends strongly to favour the ruling coalition. The ruling coalition makes excessive use of funds, abuses its control of the country's leading newspapers, television and radio networks, and misuses the government's machinery (as for extensive gerrymandering) during the campaign period (Gomez 1998).

In the Philippines, 'turncoatism'-the switching of membership of political parties-is based on a less direct form of 'candidate buying' than Thailand's. The administration or the dominant party deliberately dangles access to government funds (in particular, discretionary funds or expenditures for projects, popularly known as pork barrel) before opposition politicians as a political carrot (Leones and Moraleda 1998: $313 \mathrm{ff}$.). There are many forms of electoral irregularities in the Philippines, but massive vote-buying is the most prevalent and destructive. While the 1998 election was 'the freest, fairest, and least violent election in Philippine history', owing much to the vigilance of the media and NGOs, serious electoral inadequacies remain. For example, the use of 'write-in ballots' - which contain the names of neither candidates nor parties, but only a list of offices alongside blank lines on which the voters fill in candidates' names-prevents illiterates from voting, encourages extreme personalism, and constitutes also a disincentive to party-system development (Montinola 1999: 127-138).

South Korea is infamous for its history of political 'slush funds'. During his presidency, Roh Tae Woo received political donations amounting to about 500 billion won (US $\$ 640$ million) from more than 30 Korean business tycoons. Incidentally, the 30 largest chaebol are said to control 85 per cent of industrial South Korea (Delhaise 1998: 102). Interestingly, Roh's opponent Kim Dae Jung, who has become president in the meantime, has confessed that he received 2 billion won (US $\$ 2.5$ million) from Roh in 1992. Roh and more than 30 business tycoons, politicians 
and ex-bureaucrats were put on trial on charges of graft and corruption (Kim Y.H. 1998: 152-155). The results featured in the world press for weeks, not unreasonably scaring some authoritarian and corrupt leaders.

The formations of political parties in East and Southeast Asia are mostly deficient as they follow personalistic and clientelistic structures, not political orientations bound by values and ideas. Moreover, organizational structures within most political parties in East and Southeast Asia 'seem at least to be fragile, if not completely volatile' (Sachsenröder 1998: 1). Consequently, the party systems are unstable. For most countries in the region, political parties and democratic institutions in the opposition are weak, unstructured, suppressed and marginalized. By contrast, established ruling parties of authoritarian regimes are centralistic, undemocratic, repressive, manipulative and corrupt. East Asia has developed a 'big business party' system. Vote-buying has been perfected, and parties that have remained in power for a long time have built business empires which provide continuing financial security (Sachsenröder 1998: 20). Indonesia's Golkar, Malaysia's UMNO and Taiwan's Kuomintang appear to be among the wealthiest political parties in the world.

It may not be immediately obvious as to how electoral systems could have contributed to the Asian crisis. We have already noted that electoral manipulation is yet another form of political corruption. Thus, the arguments put forward in the section on corruption very much apply to electoral irregularities as well. Much of the corruption evident in political administrations begins even before these regimes assume office. They have their origins in the electoral process itself and even become imperative to the maintenance of political office, as politicians seek to recoup their massive outlay for the elections and retain their supporters. While the severe economic damage done by electoral irregularities such as vote-buying may be less obvious than other forms of corruption, they are nonetheless very real. 
Jürgen Rudolph and Indira Arumugam

\section{Integration of Powers, Dependent Judiciary}

In almost all of the countries in the region, rule of law is underdeveloped, and independence of the judiciary is not a given. Interpretations of the definition of judicial independence and the role of the judiciary can differ markedly from liberal views on the subject. The legal structure is also frequently thought of as 'the handmaiden of the market' or as 'one means of managing and regulating civil society' (Jayasuriya 1999b: 4, 18). Often there are blatant discrepancies between constitutional law and constitutional reality. There may be law and rule of the powerful, but no separation of powers.

Jayasuriya has drawn attention to the situation in pre-crisis Indonesia, where 'a division of power within the executive rather than a separation of power between the executive and the judiciary' seems to prevail. The executive dictates to the legislative, controls the nomination and dismissal of judges, and oversees the administration of justice. The relationship between the judiciary and the executive is based more on a patrimonial rather than corporatist model. In fact, the rule of law can serve to entrench and consolidate public or state power (Jayasuriya 1999a: 191ff., 1999b: 3). This is not restricted to Indonesia.

Among other Asian countries, the five 'crisis economies' all ranked poorly on judicial independence in the Global Competitiveness Survey (Sachs 1999). Legislation follows the interests of the powerful executive and is manipulated to legalize state actions, even at the cost of nepotism and corruption among the police, the prosecution service and judges. The judiciary is often corrupt and subservient. Recent investigations by the National Law Commission (KHN) have found that almost 80 per cent of Indonesian Supreme Court judges are tainted by bribes. (Straits Times, 26 August 2000).

Tough media laws only guarantee reporting that has been sanctioned by the government. In Indonesia, the main government means for securing a compliant press is the press publication enterprise permit, issued by the Department of Information. It replaced the existing system of publishing licences in 1992 and represented a greatly augmented censorship arsenal that allowed the government to shut down entire publishing 
enterprises as well as individual publications by judging them to be detrimental to national interests (Schwarz 1994: 239).

Apart from prestigious 'mega projects' which contributed to the economy's overheating, Malaysia also boasts 'mega defamation suits' brought by the powerful, which severely impinge on freedom of expression and press freedom. Following the example of British law, Malaysian judges are empowered to jail their own critics for 'scandalizing the court'.

The Malaysian legal system has become increasingly intolerant of criticism. In a famous case, opposition MP Lim Guan Eng was jailed for 18 months when he criticized Malaysia's legal process for stigmatizing a girl who had accused a powerful official in Dr Mahathir's administration (Pereira 1999).

The judiciary itself has not been spared from attacks from the government. In 1988, Dr Mahathir conducted a 'purge' of his country's most senior judges, whereby the lord president and two Supreme Court judges were removed from office under unprecedented and suspicious circumstances (Gomez 1998: 273). The dismissed lord president, Salleh Abas, then lamented that 'our judiciary is in shambles; it will take a whole generation to rebuild it' (Khoo 1999: 221). After this incident, the powers of the judiciary have been circumscribed to benefit the executive to such an extent that Gomez, writing before the crisis, observed a 'growing scepticism about the capacity of the judicial system to administer justice' (1998: 273). His observation turned out to be rather prophetic as Malaysia's standing has been battered by the conviction and imprisonment of former Deputy Prime Minister Anwar Ibrahim. The black eye, which was caused by the then Chief of Police, has become the symbol of Keadilan, the National Justice Party headed by Anwar's wife, Wan Azizah.

Generally, there is a dearth of laws to protect the constitutionally enshrined political freedoms, human, civil and individual rights, and to guard against discrimination on the grounds of gender, race/ethnicity, religion, etc. What few laws there are, in theory, are often flouted in practice in the name of national security. For example, security acts allow for the indefinite detention of political enemies without judicial 
Jürgen Rudolph and Indira Arumugam

proceedings. The Indonesian military's suppression of rebellions in East Timor and Aceh abounded with 'extra-judicial killings, unlawful detentions, forced confessions and torture, notwithstanding the fact that the Indonesian legal code provides protection from all these abuses' (Schwarz 1994: 247). Legislation is also frequently impaired by insufficient training of judges, the lack of clear-cut rules for the hearing of evidence, the presumption of guilt until innocence has been proven, the tacit permission of torture in order to force confessions, and the absence of fair trials. Prior to the fall of Suharto, there had been serious doubts voiced about the value of legal guarantees in a political system where candidates for the legislature had to go through a political screening.

In a Thai survey of popular opinion, the Police Department was rated as the most corrupt department of government. In a study of more than 4,000 households, it was found that one in 10 household had paid bribes in the last year; on average payments amounted to just under US $\$ 250$ with a smaller number of people saying they had paid out US $\$ 2,500$ or more. Almost 90 per cent of the bribes went to the police and the Land, Customs and Car-licensing department (East 2000). As Pasuk and Sungsidh (1996: 128) argue, corruption in the police is of particular significance as it may encourage crime. They convincingly point to the linkage between police corruption, the rule of law and democracy:

The appearance of suspected drug-runners and confessed bigtime gamblers among the ranks of MPs is the result of police corruptibility, and has an impact on the image and the functioning of democratic institutions. One key pillar of democracy is the rule of law and the opportunity of justice for all before the law. With a corrupt police, what we have is more like the rule of money and the opportunity of perverting justice for the benefit of the few' (Pasuk and Sungsidh 1996: 128).

Thailand is far from unique. Much too frequently, the role of the judiciary is reduced to being a corrupt handmaiden of the executive. You Jong Keun, a top Kim Dae Jung aide, contends that Asian societies 'did not understand the rule of law'. 
Without the rule of law, 'accountability, fair competition and transparency can be easily violated' (Asiaweek 1999: 53). In addition, checks and balances are 'logical corollaries of the doctrine of separation of powers' (Ranney 1995: 198). The integration of the three distinct kinds of power-legislative (making laws), executive (enforcing laws) and judicial (interpreting and applying laws to individual cases)-is the very definition of tyranny.

\section{Controlled Media and Weak Civil Society}

A weak civil society and media that are controlled by the government also contribute to a lack of transparency. Due to the overwhelming dominance of state institutions, the role of civil organizations is still relatively limited. The state's preponderance in Southeast Asian political cultures has been likened, rather poetically, to that of a banyan tree: nothing else is able to grow under the opulent shade cast by this tree (Vatikiotis 1996: 19).

The majority of non-governmental organizations are dependent on the state for their legal status and public funds. In Indonesia, NGOs had to register with the government within two months of their establishment, and if they lacked government approval, they risked 'intimidation and terror from the security forces' (ELSAM 1999: 160). Only a small number of institutions are truly independent bodies representing grassroots interests. These organizations obtain financing from private sources and have been vilified as unpatriotic (especially when they draw their support exclusively from Western sources) or as representing a foreign culture (Vatikiotis 1996: 191). Authoritarian regimes strive to put progressive NGOs at a disadvantage when these push for democratization, as compared to conservative groups which toe the government line. This is done mainly through legal and practical restrictions on the freedoms of assembly, association and expression (ELSAM 1999: 151).

Limits on freedom of assembly curb NGO activities without actually banning them, thus avoiding international censure. In Malaysia, a public gathering of more than five people requires a 
Jürgen Rudolph and Indira Arumugam

government permit (Vatikiotis 1996: 118). Indonesian security forces can 'easily raid and close down NGO meetings, seminars or discussions on the pretext that the organization lacks official permits' (ELSAM 1999: 161). There is mutual distrust between governmental and non-governmental institutions. Many governments feel threatened by the consciousness-raising and public education undertakings of NGOs, fearing that these activities will threaten the strategy of mass-depoliticization in favour of development (ELSAM 1999: 160).

There are, however, counter-examples. The Philippines, for instance, boasts a dynamic civil society (see Montinola 1999: 130-133). In Thailand, non-governmental development organizations (NGDOs) have become prominent in recent years (Prudhisan and Maneerat, 1997: 207-210). In Korea, civil society has become increasingly diverse, and the government engages NGOs on a wide range of issues (see Kim, B.K. 1998: 124). The extent of state intervention and crackdowns may be less in Korea, the Philippines and Thailand, but NGOs they still have to contend with restrictions.

Restrictions on the freedom of expression and the press restrict the inflow of knowledge and therefore power. The possible disruption of public order is usually cited as justification for government controls on information. In Malaysia, public order is said to be largely based on ethnic 'harmony', with racial riots functioning as a bogeyman, and newspapers belong to the government coalition. Recently, the Malaysian cabinet responded with calls to halt all open debate about Malay special rights and the affirmative action policies that they entailed after the Chinese Election Appeals Committee or Suqiu suggested that they be reviewed and sparked off protests from UMNO Youth. It was suggested that closed-door discussions would be more effective, preserving the spirit of tolerance in a multi-racial country such as Malaysia. More significantly, it was argued that Malay special rights having been constitutionally enshrined should not be discussed at all (Hamid 2000). Thus, whilst the Constitution allows for the civil rights of freedom of opinion, information, the media and assembly, these are severely curtailed on other equally constitutional grounds. 
Censorship and the depoliticization of universities are promoted. Political criticisms directed against official policies or against the structure of the political system are very risky.

Freedom of the press and other media allows a free flow of information and consequently independent thought. Though most governments in Southeast and East Asia control information and practise censorship, the increasing spread of the Internet has meant that these governments are slowly losing the information war. Not surprisingly, there is a clear connection between democratization and free media. This is demonstrated by the relative freedom enjoyed by the media in the more democratic Philippines, Thailand, Taiwan and Korea.

The spread of the Internet is vastly heterogeneous in East and Southeast Asia. Current numbers of Internet users are very difficult to determine (see Ling 1999). With the dramatic increase in users, and the near impossibility of censoring it, the Internet is expected to play a major role in the future as a means of receiving uncensored information. During the height of the Anwar Ibrahim trials as well as the recent elections, many Malaysians turned to the Internet for information and critical insights, citing the newspapers as being too biased towards the government. The Internet will thus contribute to democratization.

In a liberal democracy, the legislative, executive and judicial branches of government act as checks and balances on each other. In addition, extra-constitutional agencies such as mass media and a vibrant civil society also play a role in assuring accountability and transparency. Governments in most of the Asian region, however, regard such civilian initiatives as dangerous to order, stability and national interests. Civil society is highly dependent on information. Laws prohibiting the free flow of information are another way of debilitating NGOs. In many of the crisis countries, however, journalists risk losing their licence, livelihood, liberty and even their life if they do what they are supposed to, i.e. inform correctly and without prejudice. Fearing this, many practise self-censorship or become 'running dogs of the government' (David Marshall, quoted in Thio 1996: 71) when they should serve as watchdogs. Regimes 
Jürgen Rudolph and Indira Arumugam

that lack the checks and balances of civil society and independent media will continue to perpetuate collusion, corruption and repression.

\section{Corruption, Development and Democracy Revisited}

We have observed that corruption is rampant and, due to its prevalence in many countries in the region, severely affects economic activities. Due to electoral corruption, the most corrupt rather than the most popular political party may win and, in a court of law, the party that has paid a bribe (or the biggest bribe) may emerge victorious. We have also seen that corruption is a problem, albeit to varying degrees in all five crisis economies. According to Transparency International's (1998) highly regarded Corruption Perceptions Index, with a scale ranging from 10 denoting 'highly clean' to 0 as 'highly corrupt', they fared thus: Malaysia 5.3, Korea 4.2, Philippines 3.3, Thailand 3.0, and Indonesia 2.0. Consequently, fighting corruption on all levels will be of paramount importance in the countries plagued by this 'social cancer'.

Economic performance is highly dependent on political factors. In the long term, political legitimacy depends on accountability, responsiveness and honesty, as does political and social stability. Corruption undermines legitimacy and stability. It raises questions about a government's control over its own institutions, personnel and activities as well as its political will and capabilities. Malfeasance damages the respect for law and public and financial institutions. It erodes the credibility and effectiveness of both elected and appointed government officials (Rubin 1999).

Corruption also distorts policy and development objectives. It disrupts normal business and public-policy decision-making, benefiting the few at the expense of the many. It allows financial and human resources to be allocated to inefficient uses, often inconsistent with a nation's political and economic objectives and needs (Gray and Kaufmann 1998). The impact of corruption is even greater on less developed countries since scarce resources are diverted from critical priorities (Rubi, 
1999). The extra costs that bribery entails for businesses drive many firms underground, outside of the formal sector, undercutting the state's ability to raise revenues through taxation. Consequently, the state's ability to provide essential public goods, including the rule of law, is reduced (Gray and Kaufmann 1998). This in turn creates a conducive environment for the proliferation of crime, including organized crime. Thus, a vicious cycle of increasing corruption and underground. economic activity can occur.

Bribery rewards political ties rather than competence and competitiveness, and it privileges unearned income over entrepreneurial activity. Corruption thus undermines one of the fundamental tenets of democracy: equality of citizens' rights (della Porta 1995: 312). It also destroys morale. In a system where corruption is the norm, honest politicians and civil servants are penalized, hindering the fight against corruption.

Some have argued that corruption exists everywhere and, as a consequence, cannot be so harmful. It has even been said that bribery can have positive effects under certain circumstances, giving firms and individuals a means of avoiding burdensome regulations and ineffective legal systems (Gray and Kaufmann 1998). Corruption, however, is not the 'grease' that lubricates the 'squeaky wheels' of a rigid administration; rather, it puts the squeakiness into the wheel by creating excessive and discretionary regulations. The possibility of bribery is likely to have been the cause of the slowdown in the first place. According to the 1997 World Economic Forum's Global Competitiveness Survey, there is a positive relationship between the extent of bribery and the amount of time that enterprise managers spend with public officials (Gray and Kaufmann 1998).

Even if we should remain unconvinced that among other factors, corruption was a political cause of the crisis, it has been shown that it damages the economy. So do the other 'candidates' for political causes of the crisis that this paper has identified, such as the lack of an independent judiciary, an immature civil society, and tightly controlled mass media, which leave the government bereft of a much-needed system of checks and balances. Without them, there cannot be trans- 
Jürgen Rudolph and Indira Arumugam

parency and accountability. Consequently, the question of whether they directly contributed to the crash, contagion and crisis or did so indirectly is a mere technicality. These problem areas constitute an obstacle to sustainable development and must be reformed without further ado.

For more evidence of this we do not have to look any further than Indonesia, which is still 'hogging top spot as the biggest country risk in ASEAN' (Go 2000). This is largely due to the fact that the post-Suharto regimes have yet to divest Indonesia sufficiently of corrupt practices. By September 1999, Indonesian Corruption Watch had recorded 40 corruption cases involving figures in the Habibie administration (McBeth and Cohen, 1999: 20). President Abdurrahman Wahid's administration is also dogged by corruption allegations (Straits Times, 10 August 2000; Asmarani 2000). Corruption thus continues to cripple the Indonesian economy and prolong the crisis.

However, even Indonesia has seen the need to adopt measures to reduce corruption so as to push towards recovery. The pseudo-democratic electoral system has begun to change. But the new system is still less than ideal, as the military is allowed to nominate 38 members of parliament. Moreover, only 462 out of 700 MPR members were directly elected during the general elections of June 1999. There have also been measures put in place to tackle corruption, such as the setting up of a panel to expose and remove corrupt members of the judiciary, the appointment of 16 new Supreme Court judges, the albeit slow process to bring former President Suharto to trial, and the revoking of many of the restrictions of media considered antagonistic to the Suharto regime (Straits Times, 5 Sept. 2000). President Estrada's government has instituted a '10-point Jumpstart Anti-Corruption Programme' which involves random checks on lifestyles of politicians and bureaucrats, adequate compensatory packages, free access to public documents including government contracts, and a transparent participatory process for generating nominees for presidential appointments in government agencies (Straits Times, 30 August 2000). Undoubtedly pushed by the crash of 1997, Thailand has made substantial progress en route to a reform of the electoral 
system. Thailand has been the most alert in instituting the necessary political reforms. Since September 1997, Thailand has passed the most democratic Constitution in the country's history, which strengthens classic civil rights, reduces arbitrariness by the state and aims to have more competent and stable governments (Doner and Ramsay, 1999: 196). There is a freedom of information act, which has set loose the media hounds on every government department - as well as 11 economic reform bills, including the new laws for bankruptcy and corporate restructuring in March 1999 as well as a whole new set of laws banning insider dealings and vote-buying by officials (Friedman 1999). Moreover, an anti-corruption body has been introduced and every politician is obliged to disclose their financial circumstances. South Korea's new President Kim Dae Jung (whose election was probably only possible as a result of the Asian crisis) has begun to introduce significant reforms under difficult conditions. A comprehensive law to prevent electoral irregularities such as vote-buying has been introduced. Measures aimed at restructuring the banking system, measures improving corporate governance (especially of the chaebols) and promoting transparency have been effected (Gluck 2000).

These reforms are sporadic and may even be merely cosmetic. The changes are messy and still accompanied by lots of political wrangling and a lack of political will. It will take time to evaluate just how deeply the lessons of the economic crisis have taken root in the institutions, practices and especially the minds of the peoples in this region. There is no doubt that much more needs to be done. Civil servants need to be paid sufficiently to obviate the need for petty bribes. Backman (1999: $373 \mathrm{ff}$.) convincingly argues that many laws are rendered meaningless if they can be avoided with a small cash payment and other gifts. If there are insufficient funds to remunerate politicians and civil servants adequately, then the size of the bureaucracies should be reduced so as to ensure high wages. There must also be good clear laws that can be easily and reliably enforced. A well-supervised, soundly regulated and competitive financial system that operates on a non-personal basis should be established. Prudent banking regulations, 
Jürgen Rudolph and Indira Arumugam

auditing and accounting standards must be transparently enforced.

In the battle against corruption, political will is of utmost importance. Furthermore, justice must not only be done, it must also be seen to be done. Strong, independent anti-corruption investigative units with real authority and power have to be instituted. A few prominent people implicated for corruption must be publicly punished. This will impress upon the people the serious intentions of anti-corruption measures and prompt them to come forward with complaints and reports. Any endeavour to exterminate corruption must engage the co-operation of the citizens if it is to succeed. However, amidst the contemplation of all the changes yet to be made, there is some cause for a cautious optimism. The crisis-hit countries themselves, to a large extent seem to have taken note of the inextricable links between politics and economics and see the need for changes to the current political structure.

To return to the previously mentioned relationship between economic and political development, it is often claimed that democracy, although far from perfect, is the best system available. Some 'illiberal' democracies, such as Indonesia and Malaysia, were consolidated prior to the crisis. This consolidation, however, differs from 'democratic consolidation', in that the stability of these governments is not so much due to legitimacy, but rather achieved by coercion and ruling party hegemony (Diamond 1999). In any event, Indonesia seems to offer a counter-example. Suharto had been in power for 32 years and yet (or rather because of this fact) Indonesia was perceived as politically unstable. Thailand and South Korea, on the other hand, have seen changes of government and become more democratic, and thus have been perceived 'as more stable in the longer run' (Sadli 1999: 18).

In fact, democratization may be difficult to avoid in the long run as it seems to be exceedingly difficult to sustain authoritarian regimes indefinitely. This is not to be taken as a prediction for the next decade or so, as democratization processes and their consolidation take a long time. But there is a historical tendency which may be part of a 'fourth wave of democrati- 
zation' (Huntington 1991; Diamond 1999). Waves of democratization have one thing in common with the Asian crisis, and that is contagion. The 'successful example of one country's transition establishes it as a model for other countries to imitate; once a region is sufficiently saturated with democratic political regimes, pressure will mount, compelling the remaining autocracies to conform to the newly established norm' (Schmitter 1995: 347).

Also, authoritarian governments are undermined by both their economic failure and their economic success. Economic failure obviously makes them unpopular, while economic growth leads to increased demands for political participation. As Seymour Martin Lipset (1995a: 352) notes, in Taiwan and Korea, 'the long-term strengthening of relevant economic and social forces under military rule makes democracy feasible, while, at the same time, economic downturns or political failures may undermine the entrenched dictatorship'. Doubt has been cast on a viable, long-term future for the dominant party-states in Asia and elsewhere (see Pye 1995: 376). In Japan, the Liberal Democratic Party has lost the appearance of invincibility, while South Korea and Indonesia have experienced historical turnovers.

It has been claimed that Thailand experienced the crash of 1997 because it was democratic and therefore chaotic (see Mallet 1999: 228). But as we have seen, the chaos was rather caused by undemocratic practices within a young democracy. Similarly, the argument that the Philippines ran into trouble because it was democratic is misguided. The vulnerability and relative backwardness of the Philippine economy are very much a legacy of the sultanistic and kleptocratic Marcos years.

There is compelling quantitative evidence that the level of economic development powerfully shapes the survival prospects of democracy, and affluent democracies survive without fail. Economic growth lays the foundation for successful democratic consolidation, and there is statistical evidence that 'the more prosperous a nation is, the greater the chances are that it will sustain democracy' (Lipset 1995a: 350). With economic development, there is more equality of 
Jürgen Rudolph and Indira Arumugam

consumption, a growth of the middle class, more access to health care, more education and less illiteracy, and people are more likely to ask for increased political freedom (p. 353). On the other hand, democracy in moderate-income and especially poor countries is much more likely to last when the economy grows rapidly, with moderate inflation (see Przeworski et al. 1996: 41-42).

In the terrible history of famines in the world, no substantial famine has ever occurred in any country with a democratic form of government and a relatively free press (Sen 1999a: 92, 1999b: 7-8). Amartya Sen argues that '[the] positive role of political and civic rights applies to the prevention of economic and social disasters in general' (ibid.). Democracy's protective power was badly missed in a country like Indonesia. Corruption, on the other hand, not only increases vulnerability to crises, but is a significant impediment to implementing appropriate responses to crises (Rubin 1999). As there is a high correlation between democracy and lower levels of corruption, the conclusion is evident that democracy is not a luxury that can await the arrival of general prosperity. Democracy's merits are not regional in character - discourses such as that of 'Asian Democracy' seem to spell more of a dilution of full political democracy rather than a cultural adaptation - and neither developmental nor cultural conditions should affect the freedom of choice. Democratization in the region may be the political key to the minimization of the chances of future crises.

Jürgen Rudolph is the author of Reconstructing Identities. A Social History of the Babas in Singapore (1998) and has written journal and newspaper articles on Southeast Asian cultures, history, media and politics. He is the co-editor of two recent volumes, The Political Dimensions of the Asian Crisis (2000) and Southeast Asia into the Twenty First Century. Crisis and Beyond (2000). Dr Rudolph has studied Sociology, Philosophy, Musicology, Social Pedagogics, Social Work and Social Anthropology at universities in Erlangen (Germany), Aberdeen (Scotland) and in Singapore. He has previously held positions as Research Fellow at the Social Research 
Centre, Nuremberg (Germany); Lecturer at the Department of Sociology, University of Erlangen-Nuremberg; Research and Programme Manager at the Regional Office for East and Southeast Asia of the Friedrich Naumann Foundation in Singapore. He currently is the Training Manager of Perfect Solution in Singapore. E-mail: j_rudolph@hotmail.com

Indira Arumugam is a teaching assistant at the Department of Sociology, National University of Singapore (NUS). She is currently working on her Master's thesis on the political discourse of travel. She has written on the survival strategies of inmates in prison and Singapore Indian sociology. Her research interests include migration and travel, crime and deviance and the sociology of literature. ${ }^{5}$

E-mail: socinda@nus.edu.sg

\section{Notes}

1. This translates into, 'after it therefore because of it'.

2. There exists a vast literature on the economic and financial causes of the crisis. For a brief summary see, for instance, Rudolph 2000: 16-23.

3. Whereas corruption can be found in even the least corrupt countries, kleptocracies are defined as states that are dominated by corruption or in which corruption is a major means of capital accumulation. The term 'kleptocracy' was first used by Stanislav Andreski in 1966 as an analytical tool for polities in Africa and Latin America (Alatas 1997: 299).

4. Hing Ai Yun puts the Singapore top officials' salaries into an international perspective in her contribution to this issue.

\section{References}

Alatas, Syed Farid 1997. 'The Post-Colonial State: Dual Functions in the Public Sphere'. Humboldt Journal of Social Relations, 23 (1/2): 285-307.

Anusorn Limmanee 1988. 'Thailand'. In W. Sachsenröder and U. E. Frings (eds), vol. I, pp. 403-448.

Arndt, H.W. and Hal. Hill (eds) 1999. South East Asia's Economic Crisis Origins, Lessons and Way Forward, Singapore: Institute of Southeast Asian Studies.

Asiaweek 1999. 'Democracy and Crisis'. Asiaweek, 9 April: 52-54.

Asmarani, Devi 2000. 'Scandal-hit Gus Dur'. Straits Times, 29 August. 
Jürgen Rudolph and Indira Arumugam

Backman, Michael 1999. Asian Eclipse - Exposing the Dark Side of Business in Asia. Singapore: John Wiley \& Sons (Asia).

Bauer, Joanne R. and Daniel A. Bell (eds) 1999. The East Asian Challenge for Human Rights, Cambridge: Cambridge University Press.

Chowdhury, Neel and Anthony Paul 1997. 'Where Asia Goes From Here', http://www.fortune.com/fortune/1997/971124/whe.html

Delhaise, Philippe F. 1998. Asia in Crisis: The Implosion of the Banking and Finance Systems. Singapore: John Wiley \& Sons (Asia).

della Porta, Donatella 1995. 'Corruption'. In S. M. Lipset (ed.), Encyclopedia of Democracy. London and New York: Routledge, pp. 310-316.

Diamond, Larry 1999. Developing Democracy. Toward Consolidation. Baltimore and London: The Johns Hopkins University Press.

_ and Mark F. Plattner (eds). 1998. Democracy in East Asia. Baltimore and London: The Johns Hopkins University Press.

Doner, Richard F. and Ansil Ramsay 1999. 'Thailand: From Economic Miracle to Economic Crisis'. In Karl D. Jackson (ed), Asian Contagion: The Causes and Consequences of a Financial Crisis. Singapore: Institute of Southeast Asian Studies, pp. 171-207.

East, James 2000. 'A Cry against Graft'. Straits Times, 5 September.

(ELSAM) Institute for Policy Research and Advocacy 1999. 'Indonesia: NGOs and Popular Resistance to Authoritarian Rule'. In E. Nissan (ed.), Promoting Three Basic Freedoms: Towards Grater Freedom of Association, Assembly and Expression in Asia. Bangkok: Three Freedoms Project, pp. 151-172.

Forrester, Geoff 1999. 'Introduction'. In G. Forrester and R. J. May (eds), The Fall of Soeharto, Singapore: Select Books, pp. 1-23.

_ and R. J.May (eds). 1999. The Fall of Soeharto. Singapore: Select Books.

Friedman, Thomas. L. 1999. 'Thailand's Situation Stable after Crisis Forced Needed Changes', at:

http:/ / seattlep-i.nwsource.com/opinion/frdm19.shtml

Gluck, Caroline 2000. 'Strong show after overhaul'. Straits Times, 17 September.

Go, Robert 2000. 'It's time to stop dithering'. Straits Times, 17 September.

Godement, François 1999. The Downsizing of Asia. London: Routledge.

Gomez, Edmund Terence 1998. 'Malaysia'. In W. Sachsenröder and U. E. Frings (eds), Political Party Systems and Democratic Development in East and Southeast Asia, vol. I, pp. 226-288.

Gray, Cheryl W. and Daniel Kaufmann 1998. 'Corruption and Development'. Online at:

http://www.worldbank.org/fandd/english/0398/articles/020398.html

Haas, Robert (ed.) 1996. Human Rights and the Media. Kuala Lumpur: Asian

Institute for Development Communication. Singapore: Friedrich Naumann Foundation. 
Hamid, Wan Hamidi 2000. 'Stop Malay rights debate, says Cabinet'. Straits Times, 24 August.

Hill, Hal 1999. 'The Indonesian Economy: the Strange and Sudden Death of a Tiger'. In G. Forrester and R. J. May (eds), The Fall of Soeharto. Singapore: Select Books, pp. 93-103.

Huntington, Samuel P. 1991. The Third Wave: Democratisation in the Late Twentieth Century. Norman, OK: Oklahoma University Press.

Jackson, Karl D. 1999a. 'Introduction: The Roots of the Crisis'. In K. D. Jackson (ed), Asian Contagion: The Causes and Consequences of a Financial Crisis. Singapore: Institute of Southeast Asian Studies, pp. 1-28.

1999b. Asian Contagion: The Causes and Consequences of a Financial Crisis. Singapore: Institute of Southeast Asian Studies.

Jayasuriya, Kanishka 1999a. 'Corporatism and Judicial Independence within Statist Legal Institutions in East Asia'. In K. Jayasuriya (ed.), Law, Capitalism and Power in Asia, New York: Routledge, pp. 173-204.

— 1999b. 'Introduction: A Framework for the Studying of Legal Institutions in East Asia'. In K. Jayasuriya (ed.), Law, Capitalism and Power in Asia, New York: Routledge, pp. 1-27

1999c. Law, Capitalism and Power in Asia. New York: Routledge.

Johannen, Uwe, Jürgen Rudolphand James Gomez (eds) 2000. The Political Dimensions of the Asian Crisis. Singapore: Select Books.

Jones, Sidney 1999. 'An Overview: The Three Freedoms in Asia'. In E. Nissan (ed.), Promoting Three Basic Freedoms: Towards Greater Freedom of Association, Assembly and Expression in Asia. Bangkok: Three Freedoms Project, pp. 9-17.

Karatnycky, Adrian 1999. 'The 1998 Freedom House Survey: The Decline of Illiberal Democracy'. Journal of Democracy, 10 (1): 113-125.

Kearney, Marianne 1999. 'Indonesian Polls: Race against Time'. Straits Times, 24 April.

Khoo Boo Teik 1999. 'Between Law and Politics: The Malaysian Judiciary since Independence'. In K. Jayasuriya (ed.), Law, Capitalism and Power in Asia. New York: Routledge, pp. 205-232.

Kim Byung-Kook 1998. 'Korea's Crisis of Success'. In L. Diamond and M. F. Plattner (eds), Democracy in East Asia. Baltimore and London: Johns Hopkins University Press, pp. 113-132.

Kim Yong-Ho 1998. 'Political System: South Korea's Transition to Democracy'. In W. Sachsenröder and U. E. Frings (eds), Political Party Systems and Democratic Development in East and Southeast Asia,vol. II, pp. 132-178.

Lee, Martin 2000. 'The Asian Crisis: An Opportunity for Political Reform'. In U. Johannen, J. Rudolph and J. Gomez (eds), The Political Dimensions of the Asian Crisis. Singapore: Select Books, pp. 177-181.

Leones, Errol B. and Miel Moraleda 1998. 'The Political System in the Philippines'. In W. Sachsenröder and U. E. Frings (eds), Political Party 
Jürgen Rudolph and Indira Arumugam

Systems and Democratic Development in East and Southeast Asia, vol. I, pp. 289-342.

Ling, Connie 1999. 'Asia's Online Population Proves Hard to Pin Down'. Asian Wall Street Journal, 6 September, 1: 12.

Lipset, Seymour Martin 1995a. 'Development'. In S. M. Lipset (ed.), Encyclopedia of Democracy. London: Routledge, pp. 350-355.

- (ed). (1995b) Encyclopaedia of Democracy. London: Routledge.

McBeth, John and Margot Cohen 1999. 'Habibie Feels the Heat'. Far Eastern Economic Review, 9 September.

McLeod, Ross H. 1999. 'Indonesia's Crisis and Future Prospects'. In K. D. Jackson (ed), Asian Contagion: The Causes and Consequences of a Financial Crisis. Singapore: Institute of Southeast Asian Studies, pp. 209-240.

Mallet, Victor 1999. The Trouble with Tigers - The Rise and Fall of South-east Asia. London: HarperCollins.

Montinola, Gabriella R. 1999. 'Parties and Accountability in the Philippines,' Journal of Democracy, 10 (1): 127-140.

Nissan, Elizabeth (ed.) 1999. Promoting Three Basic Freedoms - Towards Greater Freedom of Association, Assembly and Expression in Asia. Bangkok: Three Freedoms Project.

Pasuk Phongpaichit and Sungsidh Piriyarangsan 1996. Corruption and Democracy in Thailand. $2^{\text {nd }}$ edn. Chiangmai, Thailand: Silkworm Books.

Pereira, Brendan 1999. 'Big Welcome for Freed DAP Politician'. Straits Times, 26 August.

Prudhisan Jumbala and Maneerat Mitprasat 1997. 'Non-governmental Development Organisations: Empowerment and Environment'. In Hewison 1997: 195-216

Przeworski, Adam, Michael Alvarez, Jose Antonio Cheibub and Fernando Limongi 1996. 'What Makes Democracies Endure?' Journal of Democracy, 7 (1): 50-51.

Pye, Lucian W. 1995. 'Dominant Party Democracies in Asia'. In S. M. Lipset (ed.), Encyclopedia of Democracy, London: Routledge, pp. 372-376.

Ranney, Austin 1995. 'Checks and Balances'. In S. M. Lipset (ed.), Encyclopedia of Democracy, London: Routledge, pp. 198-200.

Rubin, Robert 1999. 'Statement of Treasury Secretary Robert E. Rubin. A Global Forum on Fighting Corruption: Safeguarding Integrity among Justice and Security Officials'. Oniline at:

http://www.ustreas.gov/press/releases/pr2975.htm

Rudolph, Jürgen 2000. 'The Political Causes of the Asian Crisis'. In U. Johannen, J. Rudolph and J. Gomez (eds), The Political Dimensions of the Asian Crisis. Singapore: Select Books, pp. 13-93.

Rushdie, Salman 1997. 'A Land of Plenty'. Time, 11 August.

Sachs, Jeffrey 1999. 'Missing Pieces'. Far Eastern Economic Review, 25 February. 
Sachsenröder, Wolfgang 1998. 'Party Politics and Democratic Development in East and Southeast Asia - a Comparative View'. In W. Sachsenröder and U. E. Frings (eds), Political Party Systems and Democratic Development in East and Southeast Asia. Aldershot: Ashgate, Vol. 1, pp. 1-35.

- and Ulrike E. Frings (eds) 1998. Political Party Systems and Democratic Development in East and Southeast Asia, 2 vols, Aldershot, England: Ashgate.

Sadli, Mohammad (1999) 'The Indonesia Crisis'. In H. W. Arndt and H. Hill (eds), 16-27.

Schmitter, Philippe C. 1995. 'Waves of Democratisation'. In S. M. Lipset (ed), Encyclopedia of Democracy. London: Routledge, pp. 326-349.

Schumpeter, Joseph 1947. Capitalism, Socialism and Democracy. $2^{\text {nd }}$ edn. New York: Harper.

Schwarz, Adam 1994. Indonesia in Waiting: Indonesia in the 1990s. Sydney: Allen \& Unwin.

Sen, Amartya 1999a. 'Human Rights and Economic Achievement'. In J. R. Bauer and D. A. Bell (eds), pp. 88-102.

— 1999b. 'Democracy as a Universal Value'. Journal of Democracy, 10 (3): 317.

Shang-Jin Wei and Sara E. Sievers 1999. 'The Cost of Crony Capitalism'. Straits Times, 4 July.

Straits Times 1999a. 'Corruption has Doubled Asian Costs, Says ADB'. Straits Times, 27 April.

_ 1999b. 'Uproar over No Politics for Lawyers'. Straits Times, 2 October.

_ 2000a. 'President Called to Testify in Embezzlement Case'. Straits Times, 10 August.

- 2000b. ' $80 \%$ of Top JudgesAre Corrupt: Panel'. Straits Times, 26 August.

- 2000c. 'Estrada Will Undergo Lifestyle Check Too'. Straits Times, 30 August.

2000d. 'Aburrahman Appoints 16 New Judges' Straits Times, 5 September. Thio Li-ann 1996. 'Singapore'. In R. Haas (ed), Human Rights and the Media. Kuala Lumpur: Asian Institute for Development Communication. Singapore: Friedrich Naumann Foundation, pp. 69-77.

Transparency International 1998. '1998 Corruption Perceptions Index'. http:/ /www. wdg.de/ uvw/CPI1998.html

United Nations Development Programme (UNDP) 2000. 'Achievement in Governance'. Online at:

http://www.undp.org/toppages/govern/govframe.htm

Vatikiotis, Michael R. J. 1996. Political Change in Southeast Asia: Trimming the Banyan Tree. London: Routledge. 